\title{
Membrane degradation model for 3D CFD analysis of fuel cell performance as a function of time
}

\author{
L. Karpenko-Jereb ${ }^{a, *}$, C. Sternig ${ }^{a}$, C. Fink ${ }^{b}$, R. Tatschl ${ }^{b}$

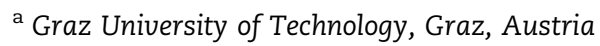 \\ ${ }^{\mathrm{b}}$ AVL List GmbH, Graz, Austria
}

\section{A R T I C L E I N F O}

\section{Article history:}

Received 2 March 2016

Received in revised form

21 May 2016

Accepted 23 May 2016

Available online 23 June 2016

\section{Keywords:}

Polymer electrolyte fuel cell

Nafion degradation

Modelling

Computational fluid dynamics

Local operating condition

\begin{abstract}
A B S T R A C T
The paper describes a development of a degradation model, which enables to predict timedependent changes in performance of a polymer electrolyte fuel cell. The developed model consists of two main parts: 1) a new semi-empirical model taking into account changes in physico-chemical properties of a polymer electrolyte membrane operating in the fuel cell, 2) a validated CFD model computing the $3 \mathrm{D}$ performance of the cell. In the semi-empirical model, the degradation rates of the membrane thickness and conductivity depend on the oxygen crossover rate. The acid group concentration is calculated from the membrane conductivity based on the percolation theory approach. The gas diffusion coefficients are modelled empirically as a function of the membrane thickness.

The model of the membrane degradation is coupled with the CFD model and applied to analyse the cell behaviour as a function of time. The simulation shows that the cell current density decreases faster with lowering relative humidity and increasing temperature. The in-plane degradation of the membrane is non-uniform and depends on the local operating condition.
\end{abstract}

๑) 2016 Hydrogen Energy Publications LLC. Published by Elsevier Ltd. All rights reserved.

\section{Introduction}

One of the most important tasks prior to start series production is to reduce the costs of PEMFC systems and to improve their durability [1-5]. Only an optimal usage of the potential of PEMFC stacks will satisfy the targets. In order to define the optimal operating conditions it is necessary to know the realtime changes in the material properties of the PEMFC and correlations between material degradation rates and operating conditions. Currently, creation of a proper degradation model, which might enable to predict the PEMFC performance as a function of operating time, is in great demand [6-9].

The present work focuses on 1) analysis of existing theoretical approaches which are used to model degradation phenomena in the PEMFCs and to predict their lifetime, 2) creation of a semi-empirical model of the degradation of the polymer electrolyte membrane, which can be applied to 3D CFD analysis of the PEMFC performance in a degraded state.

List of abbreviations: 1D, one-dimensional; 3D, three-dimensional; CD, current density; CFD, computational fluid dynamics; CL, catalyst layer; DFT, density functional theory; FC, fuel cell; FTA, fault-tree analysis; GDL, gas diffusion layer; HF, Hartree-Fock; IEC, ionexchange capacity (acid group concentration); MD, molecular dynamics; PEM, polymer electrolyte membrane; PEMCC, polymer electrolyte membrane coated with catalyst layer; PEMFC, polymer electrolyte membrane fuel cell; RH, relative humidity.

* Corresponding author. NAWI Graz, Graz University of Technology, Institute of Physical and Theoretical Chemistry, Austria. Tel.: +43 31687332 241; fax: +4331687332202.

E-mail address: larisa.karpenko-jereb@tugraz.at (L. Karpenko-Jereb). 


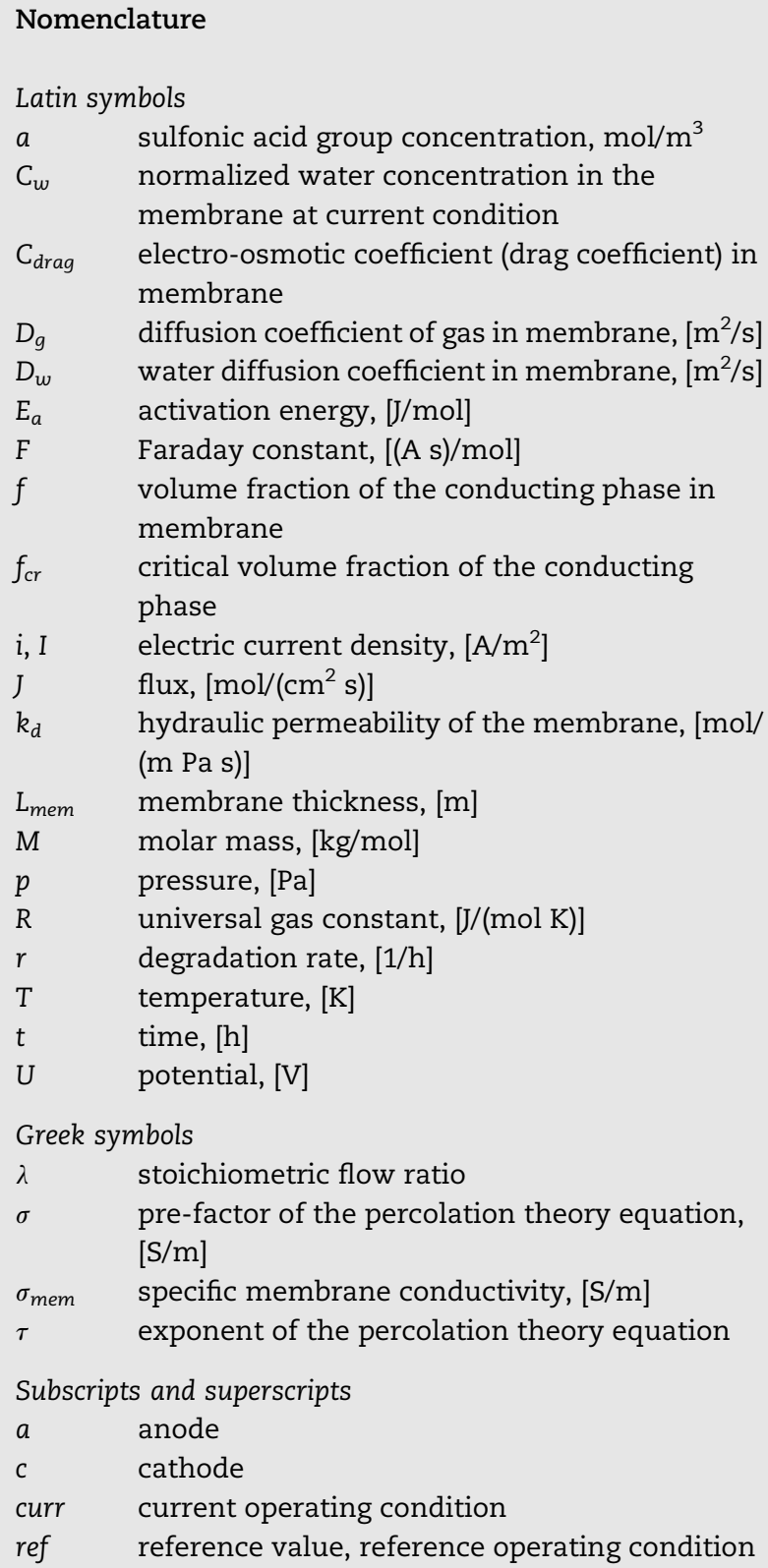

The degradation processes taking place in an operating fuel cell and their reasons have been discussed and analysed in papers [10-16]. The experimental investigations $[17,18]$ have reported that, at conventional operating condition, the polymer electrolyte membrane degrades much faster than the gas diffusion and the catalyst layers. Also, the theoretical estimations using Fault-Tree Analysis (FTA) (Table 1) showed that

Table 1 - Degradation rates of PEMFC materials, estimated using Fault Tree Analysis and reported in Ref. [19].

\begin{tabular}{lc} 
Degraded components of PEMFC & Degradation rates, [V/h] \\
\hline Polymer electrolyte membrane & $7.34 \times 10^{-5}$ \\
Catalyst layer & $7.42 \times 10^{-11}$ \\
Gas diffusion layer & $2.45 \times 10^{-14}$ \\
\hline
\end{tabular}

at cycling operation, a drop of a fuel cell potential is mainly caused by the membrane degradation [19].

The degradation processes in Polymer Electrolyte Membranes can be divided into three main groups: 1) mechanical destruction causing pinhole and crack formation in the polymer; 2) chemical degradation dealing with decomposition of the polymer chain via chemical reaction with hydrogen peroxide free radicals; 3 ) thermal degradation taking place at high temperature $\left(>150^{\circ} \mathrm{C}\right)$ and leading to membrane dry-out and decomposition of sulfonyl functional groups.

Brujin [10] reported that for a long-term performance of the fuel cell, the relative humidity has to be close to $100 \%$ and the temperature not higher than $75^{\circ} \mathrm{C}$. At those operating conditions, the voltage degradation can be lower than $1-2 \mu \mathrm{V} / \mathrm{h}$. This estimation corresponds to the simulation results obtained using FTA as shown in Table 1 . However, the degradation rates can increase by orders of magnitude when conditions include some of the following: 1) load cycling; 2) start-stop cycles; 3) temperature cycling; 4) low humidification; 5) humidification cycling; 6) temperature of $90{ }^{\circ} \mathrm{C}$ or higher; 7) fuel starvation.

Brief overview of published PEMFC degradation models. At the last decade, numerous degradation models have been published [19-43]. Most of the models consider degradation phenomena in a single component of the fuel cell: either in the membrane $[21,25,28,29]$, or in the catalyst layer $[20,23,24,26,27,30]$, or in the gas diffusion layer [22]. There are much less models predicting durability [19,34,35,40-44] or performance [25,33-39] of a complete fuel cell or stack. In accordance to utilized theory and a level, on which degradation phenomena are described, the models can be divided into the following categories (Table 2): 1) micro-scale; 2) macro-scale; 3 ) multi-scale models. The micro-scale models describe the degradation processes on atomic and molecular levels using approaches of quantum-chemistry such as Density Functional Theory (DFT), Hartree-Fock Method (HF), molecular-dynamics (MD) and Monte-Carlo methods. The macro-scale models are usually based on the transport models by taking into account the kinetics of the chemical reactions of the degradation. These

\begin{tabular}{|c|c|c|}
\hline Considered domain & Level & Methods \\
\hline Single component: & Micro-scale & Ab-initio $[20,21]$ \\
\hline Polymer electrolyte & & Molecular dynamics [22] \\
\hline membrane & & Monte Carlo [23] \\
\hline Catalyst layer & Macro-scale & Kinetic models \\
\hline Gas diffusion layer & & $\begin{array}{l}\text { coupled with transport } \\
\text { models [24-32] }\end{array}$ \\
\hline \multirow[t]{4}{*}{ Single fuel cell } & Macro-scale & Equivalent circuit model [33] \\
\hline & & Fault tree analysis $[19,34]$ \\
\hline & & $\begin{array}{l}\text { Neutral network } \\
\text { modelling [35] }\end{array}$ \\
\hline & Multi-scale & $\begin{array}{l}\text { Ab initio + CFD } \\
\text { simulation }[36-39]\end{array}$ \\
\hline \multirow[t]{4}{*}{ Fuel cell stack } & Macro-scale & Semi-empiric model [40] \\
\hline & & Fault tree analysis [41] \\
\hline & & Petri nets [42] \\
\hline & & $\begin{array}{l}\text { Particle filtering } \\
\text { framework }[43,44]\end{array}$ \\
\hline
\end{tabular}


models are able to predict changes in the macro-properties of the fuel cell materials and cell performance.

The models based on the deductive failure analysis $[19,34,35,41-44]$ we also refer to the macro-scale models. These models have been applied to estimate a reliability, durability as well as lifetime of single fuel cell or complete fuel cell stacks using Fault Tree Analysis (FTA) $[19,34,41]$ or Petri Nets [42]. Also, the models of Prognostics and Health Management (PHM) are used to control the PEMFC performance and to predict the Remaining Useful Life (RUL) of a single cell or stack before a failure occurs [43,44]. Zhang et al. [43] applied Kalman filter framework based on a linear quadratic estimation and series of measurements observed over time to estimate the damage of a single fuel cell. For this purpose the model based on PHM framework was coupled with a physics-based, prognostic-oriented catalyst degradation model by taking into account the relationship between the operating conditions and the degradation rate of the electro-chemical surface area. Jouin et al. [44] utilized a particle filtering approach and two data sets to estimate a lifetime of a complete stack. The model predictions demonstrated an accuracy of $90 \mathrm{~h}$ around the real value of the RUL for a $1000 \mathrm{~h}$ lifespan. A disadvantage of the models based on deductive failure analysis and prognostics is that the models are not applicable to an advanced analysis of the fuel cell performance in degraded state.

The advanced 3D analysis of the PEMFC is possible using the CFD simulation. Currently, only a single model enables the CFD simulation of the PEMFC in a degraded state. It is the multiscale model suggested by Franco et al. [36-39]. This multi-scale model combines [36] simulations on different scales: DFT and MD is used for the calculations of the kinetic parameters of the electrochemical reactions, Monte Carlo approach is applied to simulate parameters of Pt catalyst in degraded state and the CFD method is used to predict the fuel cell performance at a certain point of time. However, this model has some shortcomings. On the one hand, the ageing processes in the catalyst layer are modelled using ab-initio molecular dynamics approaches, which require suitable computing resources and the calculations are very timeconsuming. On the other hand, model assumed that the degradation phenomena in the polymer electrolyte membrane are negligible, although, the numerous studies demonstrated that, at conventional operating condition, the PEMFC damage is significantly affected by a chemical destruction of the polymer electrolyte membrane $[18,19,32]$. It should be mentioned, that the recent theoretical study [45] on the influence of material properties on the PEMFC performance showed that, the changes in the membrane characteristics substantially impact the PEMFC behaviour.
Objective of the present work. We undertake an attempt to create a new model for 3D CFD analysis of the PEMFC as a function of time under consideration of the degradation phenomena in the polymer electrolyte membrane. The new model consists of two main parts: the first part is a semiempirical model computing time-dependent changes in the membrane. The semi-empirical model takes into account the influence of the operating conditions (temperature, relative humidity and voltage) on the degradation rates. The second part is the performance model of the PEMFC using the CFD code AVL FIRE ${ }^{\circledR}$ [46]. The membrane characteristics calculated in the first model are used as input parameters for the CFD code AVL FIRE ${ }^{\circledR}$ in order to simulate the fuel cell performance at certain points of time. The theoretical description of the changes in the PEM characteristics is based on the data published in the scientific papers [47-56].

The degradation rates of the membrane thickness and conductivity used as input data in the semi-empirical model of the membrane degradation are listed in Table 3. These degradation rates are estimated from the experimental data reported by Yuan et al. $[57,58]$. The degradation rate of the membrane conductivity is calculated from in-situ measurements [57] of the high-frequency resistance assuming that the membrane thickness linearly decreases during the cell degradation. The degradation rate of the membrane thickness is calculated from the ex-situ measurements [58]. The mentioned experiments $[57,58]$ were carried out on a four-cell stack with an active area of $50 \mathrm{~cm}^{2}$, at $\mathrm{T}=70{ }^{\circ} \mathrm{C}$; $\mathrm{RH}=100 \%$; $\mathrm{p}_{\mathrm{a}}=\mathrm{p}_{\mathrm{c}}=1$ bar. The materials used were Ion Power catalyst four coated membranes (Nafion 117, Nafion 115, NR212, and NR211) with a Pt catalyst loading of $0.3 \mathrm{mg} / \mathrm{cm}^{2}$ supported on carbon on both sides and SGL gas diffusion layers. The degradation of the stack was investigated for $1000 \mathrm{~h}$ under idle operation, at I $=0.5$ A $\left(10 \mathrm{~mA} / \mathrm{cm}^{2}\right)$, ca. U 0.98-1 V. The performance of the individual cells was analysed at different times during the degradation process.

The authors of the papers $[57,58]$ showed that the changes in the cell performance was caused mainly by the membrane degradation and practically no degradation of the catalyst layer was observed after $1000 \mathrm{~h}$. Therefore, we take these experimental data from Refs. $[57,58]$ for the preliminary testing of the newly developed membrane degradation model.

\section{Membrane degradation model}

\section{Approximations}

1) The model developed is able to predict time-dependent changes in the physico-chemical properties of the

Table 3 - Input values of the Membrane Degradation Model utilized in the simulation.

\begin{tabular}{|c|c|c|c|c|c|}
\hline $\begin{array}{l}\text { Degradation rate of } \\
\text { the membrane }\end{array}$ & Symbol & Unit & Value & Source & Comments \\
\hline Ionic conductivity & $r_{\sigma_{m e m}}^{r e f}$ & $1 / \mathrm{h}$ & $5.64 \times 10^{-4}$ & [57] & $\begin{array}{l}\text { The value is estimated from the experimental data using the } \\
\text { expression: } r_{\sigma_{\text {mem }}}^{\text {ref }}=\left[\sigma_{\text {mem }}^{0}-\sigma_{\text {mem }}^{t}\right] /\left[t \times \sigma_{\text {mem }}^{0}\right]\end{array}$ \\
\hline Thickness & $r_{L_{m e m}}^{\text {ref }}$ & $1 / \mathrm{h}$ & $3.71 \times 10^{-4}$ & [58] & $\begin{array}{l}\text { The value is estimated from the experimental data using the } \\
\text { expression: } r_{L_{\text {mem }}}^{r e f}=\left[L_{\text {mem }}^{0}-L_{\text {mem }}^{t}\right] /\left[t \times L_{\text {mem }}^{0}\right]\end{array}$ \\
\hline
\end{tabular}


perfluorinated membrane of Nafion type at following operating conditions: $\mathrm{T}=25-100{ }^{\circ} \mathrm{C}, \mathrm{RH}=25-100 \%$, $\mathrm{p}_{\mathrm{c}}=\mathrm{p}_{\mathrm{a}}=1 \mathrm{bar}, \mathrm{U}=0.4-1.2 \mathrm{~V}$. The model is developed for the case, when gas pressure gradient through the membrane is negligible. In this case, the transport of hydrogen and oxygen through the membrane proceeds only via diffusion caused by the concentration gradient.

2) The model computes the changes caused by the chemical degradation in the membrane thickness, ionic conductivity, acid group concentration as well as the crossover diffusion of $\mathrm{H}_{2}, \mathrm{O}_{2}$ and $\mathrm{N}_{2}$.

3) The degradation rates of the membrane properties are modelled as functions of the temperature, relative humidity and cell voltage.

4) The degradation rates of the membrane thickness and ionic conductivity depend on the $\mathrm{O}_{2}$ crossover rate through the membrane.

5) The relative changes in the acid group concentration is proportional to the relative decrease in the membrane conductivity. This correlation is derived from the percolation theory approach utilized to ion-exchange materials [47].

6) It is assumed that pinholes in the membrane occur when the membrane thickness decreases to a critical thickness, $L_{\text {mem }}^{c r}$. Further decrease in the membrane thickness (at $\mathrm{L}_{\text {mem }}^{\mathrm{t}}<\mathrm{L}_{\text {mem }}^{\mathrm{cr}}$ ) leads to a dramatic increase of the gas crossover diffusion.

\section{Membrane thickness and conductivity}

The chemical destruction of the perfluorinated sulfonated membranes is mainly caused by interaction of the hydroxyl radicals with the membrane polymer chains. The basic

a)

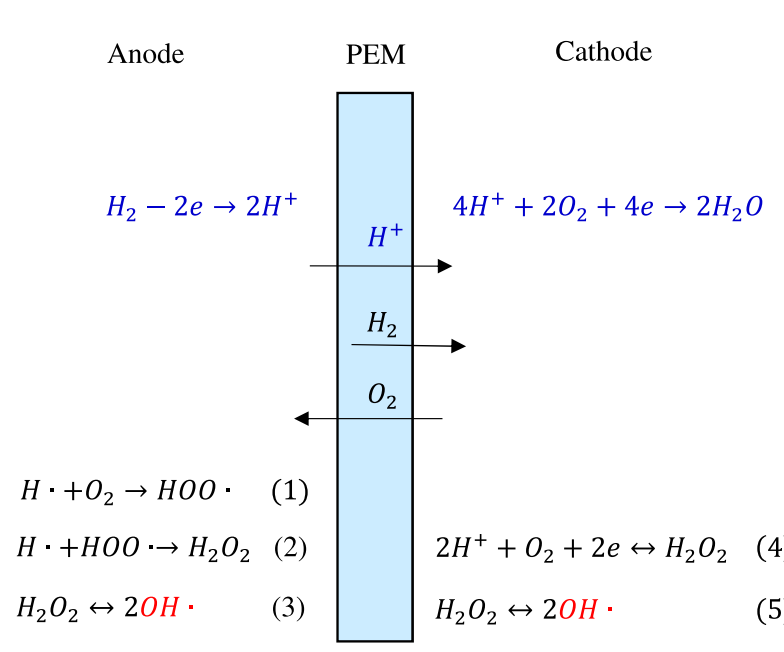

reactions (1)-(3) of the radical formation, which could take place in the polymer electrolyte fuel cell are presented in Fig. 1. One possible mechanism of Nafion destruction is unzipping of the polymer main chains (backbone) proceeding in accordance to reactions (6)-(8) [28,31]. These reactions result in shorting main chains and consequently in loss of the equivalent weight of the polymer. Other studies $[21,48,49]$ have proved a degradation of the side chains corresponding to reactions (9)-(11). In this case, hydroxyl radicals attack $\mathrm{C}-\mathrm{O}$ bonds in the ether groups of the side chains. The reactions (9)-(11) lead to loss of the parts of the side chains containing the functional groups. The mechanism results in a decrease of the polymer equivalent weight as well as in lowering of the membrane conductivity.

Fig. 2 presents evolution of the membrane thickness during the degradation (a) and a dependence of the hydrogen crossover diffusion current density vs operating time (b). We assume, that the mechanical defects (pinholes and cracks) in the membrane occur at some critical membrane thickness, $\mathrm{L}_{\mathrm{mem}}^{\mathrm{cr}}$. After the pinholes emerge (at $L_{\text {mem }}^{\text {curr }} \leq L_{\text {mem }}^{c r}$ ), the hydrogen flux through the membrane dramatically rises resulting in an pronounced increase of the hydrogen crossover current density as indicated in Fig. 3b [50].

According to the reactions (6)-(11), the degradation kinetics of the polymer depends on the hydroxyl radical concentration in the membrane, which correlates with the oxygen concentration. Since at the considered operating condition $\left(\mathrm{p}_{\mathrm{c}}=\mathrm{p}_{\mathrm{a}}=1\right.$ bar, i.e. $\left.\Delta \mathrm{p}=0\right)$, the oxygen concentration is determined by $\mathrm{O}_{2}$ crossover diffusion, we can formulate the following correlation between the membrane degradation rate and $\mathrm{O}_{2}$ crossover rate: b)

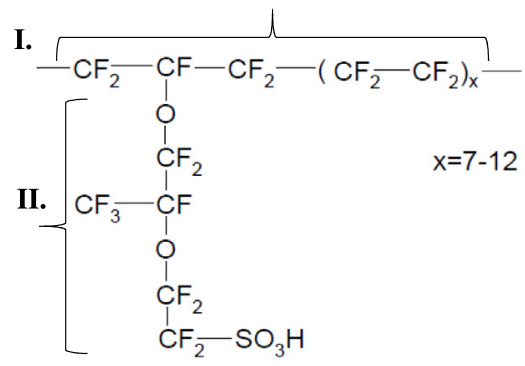

Unzipping of backbone (I):

$\mathrm{R}-\mathrm{CF}_{2} \mathrm{COOH}+\mathrm{OH} \cdot \rightarrow \mathrm{R}-\mathrm{CF}_{2} \cdot+\mathrm{CO}_{2}+\mathrm{H}_{2} \mathrm{O}$

$\mathrm{CF}_{2} \cdot+\mathrm{OH} \rightarrow \mathrm{R}-\mathrm{CF}_{2} \mathrm{OH} \rightarrow \mathrm{R}-\mathrm{COF}+\mathrm{HF}$

$\mathrm{R}-\mathrm{COF}+\mathrm{H}_{2} \mathrm{O} \rightarrow \mathrm{R}-\mathrm{COOH}+\mathrm{HF}$

Splitting of the side chain (II) with functional group:

$\mathrm{R}-\mathrm{R}^{\prime}-\mathrm{SO}_{3}^{-}+\mathrm{OH} \rightarrow \mathrm{R}-\mathrm{OH}+\mathrm{OCF}_{2} \mathrm{CF}\left(\mathrm{CF}_{3}\right) \mathrm{O}\left(\mathrm{CF}_{2}\right)_{2} \mathrm{SO}_{3}^{-}$

$R-\mathrm{R}^{\prime}-\mathrm{SO}_{3}^{-}+\mathrm{OH} \rightarrow \mathrm{R}-\mathrm{OCF}_{2} \mathrm{CF}\left(\mathrm{CF}_{3}\right) \mathrm{O}+\mathrm{HO}\left(\mathrm{CF}_{2}\right)_{2} \mathrm{SO}_{3}^{-}$

$\mathrm{R}-\mathrm{OCF}_{2} \mathrm{CF}\left(\mathrm{CF}_{3}\right) \mathrm{O}+\mathrm{H}_{2} \mathrm{O}+\mathrm{OH} \rightarrow \mathrm{R}-\left(\mathrm{CF}_{2}\right)_{n} \mathrm{COOH}+\mathrm{HF}$

Fig. 1 - a) Proton and gas transport through the Polymer Electrolyte Membrane (PEM) and electrochemical reactions at anode and cathode: (1)-(3) - formation of hydrogen peroxide radicals at the anode; (4)-(5) - formation of hydrogen peroxide radicals at the cathode. b) Chemical structure of the perfluorinated membrane of Nafion type: (I) - main chain of the polymer (R), (II) - the side chain containing the functional group $\left(R^{\prime}\right),(6)-(8)$ - unzipping mechanism of the polymer main chain (backbone) of the perfluorinated membrane; (9)-(11) - splitting mechanism of the polymer side chain, containing functional (acid) group. 
a)
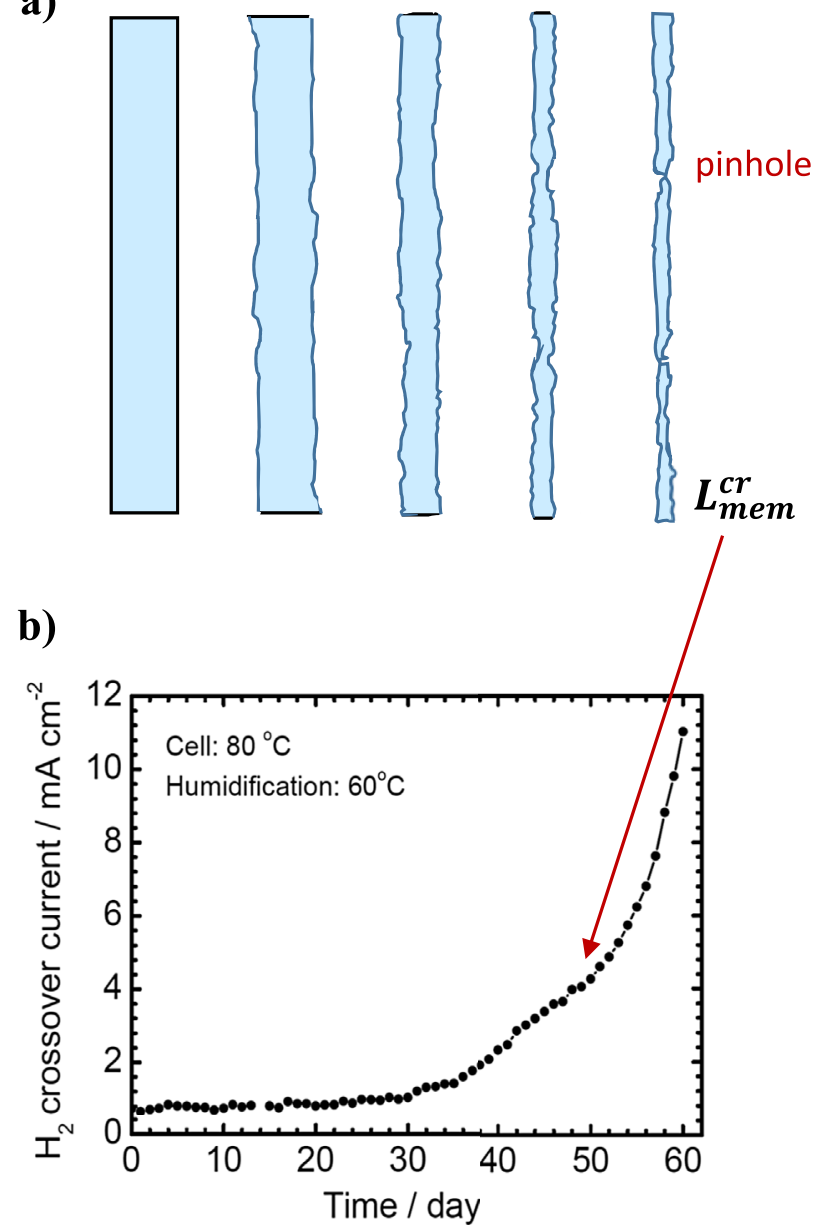

Fig. 2 - Model visualization of the membrane degradation during the fuel cell operation: (a) - the decrease in the membrane thickness and formation of pinholes; (b) experimental data on the time changes of hydrogen crossover diffusion current density, published by Inaba et al. [50] (reprinted with permission from Elsevier).

$r^{\text {curr }}=r^{r e f} \cdot \frac{J_{\mathrm{O}_{2}}^{\text {curr }}}{J_{\mathrm{O}_{2}}^{\text {ref }}}$

where $r^{r e f}[1 / \mathrm{h}], \mathrm{O}_{\mathrm{O}_{2}}^{\mathrm{ref}}\left[\mathrm{mol} /\left(\mathrm{cm}^{2} \cdot \mathrm{s}\right)\right]-$ degradation rate and oxygen crossover rate through the membrane at reference operating condition of the fuel cell; $r^{\text {curr }}, J_{\mathrm{O}_{2}}^{\text {curr }}-$ degradation rate and oxygen flux crossover through the membrane at current operating condition. Eq (1) means, when a degradation rate of the membrane is known for certain operating condition, other degradation rates at other operating conditions can be estimated.

In order to simplify the calculation of the ratio of the $\mathrm{O}_{2}$ crossover fluxes at two different operating conditions, we utilize Eq (2) suggested by Baik et al. [51] to fit experimental data of the hydrogen crossover rate as a function of the pressure gradient, temperature, relative humidity and membrane thickness. The hydrogen crossover rate was measured for five perfluorinated membranes Nafion with thicknesses from 20 to $250 \mu \mathrm{m}$ at varied single operating parameter

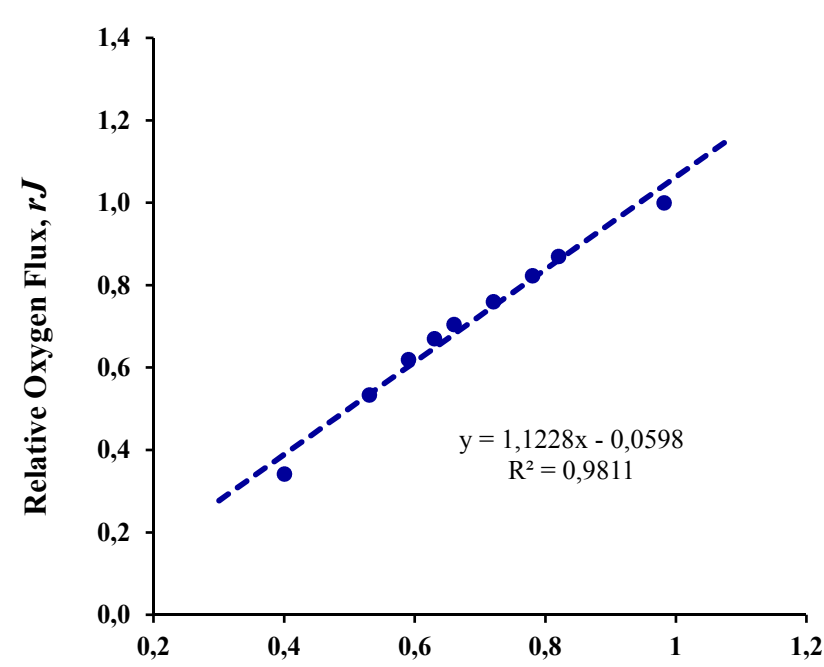

Cell Voltage, [V]

Fig. 3 - The relative change ( $r J)$ of the $\mathrm{O}_{2}$ crossover flux through the membrane depending on the cell voltage. $r$ is calculated from the oxygen crossover flux at a current density related to them at the open circuit voltage $\left(r J=J_{\mathrm{O}_{2}}(U) / J_{\mathrm{O}_{2}}^{\text {ocv }}\right)$. In the simulated case, $\mathrm{U}(\mathrm{OCV})=0.98 \mathrm{~V}$. In the figure, the points are computed using the basic PEMFC model of the CFD code AVL FIRE on single channel fuel cell for Nafion 115 with $L_{\text {mem }}=124 \mu \mathrm{m}$; at $T=70^{\circ} \mathrm{C}$, $\mathrm{RH}=100 \%, \mathrm{p}_{\mathrm{c}}=\mathrm{p}_{\mathrm{a}}=1 \mathrm{bar}$. The dashed line is linear correlation used in the developed model.

keeping other parameters constant. The investigated ranges of the parameters were $\mathrm{T}=25-85{ }^{\circ} \mathrm{C} ; p_{\mathrm{H}_{2}}=1-2 \mathrm{bar}$; $\mathrm{RH}=25-100 \%$. Using multiple linear regression for the analysis of the obtained data the authors suggested the generalized mathematical expression:

$J_{H_{2}}=a_{0}+a_{1} \cdot T+a_{2} \cdot R H+a_{3} \cdot p+a_{4} \cdot\left(\ln \left(L_{m e m}\right)\right)^{-1}$

where $a_{0}=-2.6492 ; \quad a_{1}=0.0180 ; \quad a_{2}=0.0036 ; \quad a_{3}=0.5992$; $a_{4}=10.840$. In this expression $\mathrm{p}$ is the hydrogen pressure at the anode. In this equation $\mathrm{T}=\left[{ }^{\circ} \mathrm{C}\right] ; \mathrm{RH}=[\%] ; \mathrm{p}=[\mathrm{bar}]$; $\mathrm{L}_{\text {mem }}=[\mu \mathrm{m}], J_{\mathrm{H}_{2}}=\left[\mathrm{mol} /\left(\mathrm{cm}^{2} \cdot \mathrm{s}\right)\right]$. The study showed, that the minimal hydrogen crossover rate is observed for the thickest membrane $\left(\mathrm{L}_{\text {mem }}=250 \mu \mathrm{m}\right)$ and low temperature $\left(\mathrm{T}=25^{\circ} \mathrm{C}\right)$, relative humidity $(\mathrm{RH}=25 \%)$.

Because both hydrogen and oxygen are non-polar molecules and do not have any special interactions with perfluorinated ionomer membranes, the tendency obtained for hydrogen crossover could be applicable to oxygen crossover, though the oxygen permeability is lower than of the hydrogen's one. As shown in Refs. [52-54], the ratio of oxygen to hydrogen crossover flux through Nafion membranes does practically not depend on environment conditions such as $\mathrm{T}$, $\mathrm{p}, \mathrm{RH}$ and can be considered as a constant value, i.e $\mathrm{J}_{\mathrm{O}_{2}}^{\text {curr }} / \mathrm{J}_{\mathrm{O}_{2}}^{\text {ref }}=\mathrm{J}_{\mathrm{H}_{2}}^{\text {curr }} / \mathrm{J}_{\mathrm{H}_{2}}^{r e f}=$ const. In absence of the gas pressure gradient through the membrane (at $\mathrm{p}_{\mathrm{c}}=\mathrm{p}_{\mathrm{a}}=1 \mathrm{bar}$ ), we use the following relation: 
$\frac{J_{\mathrm{O}_{2}}^{\text {curr }}}{J_{\mathrm{O}_{2}}^{\text {ref }}}=\frac{\left[a_{0}+a_{1} \cdot T^{\text {curr }}+a_{2} \cdot R H^{\text {curr }}+a_{3}+a_{4} / \ln \left(L_{\text {mem }}^{\text {curr }}\right)\right]}{\left[a_{0}+a_{1} \cdot T^{\text {ref }}+a_{2} \cdot R H^{r e f}+a_{3}+a_{4} / \ln \left(L_{\text {mem }}^{\text {ref }}\right)\right]}$

It should be mentioned that we use Eq (3) to calculate the degradation rate of the membrane thickness and membrane conductivity at the open circuit potential. In order to consider an influence of the cell voltage on the oxygen crossover flux, we analysed the simulation results obtained using CFD code AVL FIRE and presented them in Fig. 3. In Fig. 3. $r \mathrm{O}_{\mathrm{O}_{2}}-$ the oxygen crossover flux related to the flux at the open circuit voltage (OCV). The simulation presented is carried out on the single channel cell described below, for Nafion 115 at conventional operating conditions $\mathrm{T}=70{ }^{\circ} \mathrm{C}, \mathrm{RH}=100 \%$, $\mathrm{p}_{\mathrm{a}}=\mathrm{p}_{\mathrm{c}}=1 \mathrm{~atm}$. The material parameters as well as the boundary conditions applied in the simulation are described in detail in the next section "Simulation Setup". The calculated data on the relative change of the oxygen crossover flux as a function of the voltage (for the voltages $0.4 \leq U \leq 1.2$ ) is well described by the linear fitting:

$r J=\frac{\mathrm{O}_{2}^{\text {curr }}(U)}{J_{\mathrm{O}_{2}}^{\text {curr }}}=1.12 \cdot U-0.06$

Taking into account Eqs (2), (4) and (5), the calculation of the membrane degradation rate follows: parameters lie in the intervals: $f=0.15 \pm 0.03, \tau=1.6 \pm 0.4$ [47]. The volume fraction $f$ in the polymer electrolyte membrane is calculated using Eq (9):

$f=\operatorname{IEC} \cdot\left(\mathrm{M}_{\mathrm{SO}_{3}}+\mathrm{M}_{w} \cdot \mathrm{C}_{w}\right)$

where IEC - acid group concentration (here, in [mol/ $/ \mathrm{kg}]$ ), $\mathrm{M}_{\mathrm{SO}_{3}}$ - molar mass of the functional group $\left(\mathrm{SO}_{3}\right), \mathrm{C}_{w}$ - hydration number of the functional group (number of water molecules per one sulfo-group) in the polymer electrolyte membrane; $M_{w}$ molar mass of water. The derivation of Eq (9) has been described in Ref. [47].

Assuming, that $C_{w}$ does not change during the degradation process, the following relation between the membrane conductivity and acid group concentration is obtained:

$\frac{\sigma_{m e m}^{t}}{\sigma_{m e m}^{0}}=\left(\frac{a^{t}}{a^{0}}\right)^{1 / \tau}$

Taking into account Eq (10) for the calculation of the membrane conductivity as a function of time, the following equation is obtained to calculate the acid group concentration:

$a^{t}=a^{0} \cdot\left(\frac{\sigma_{m e m}^{t}}{\sigma_{m e m}^{0}}\right)^{\tau}$

$r^{\text {curr }}(U)=r^{r e f} \cdot \frac{\left[a_{0}+a_{1} \cdot T^{\text {curr }}+a_{2} \cdot R H^{\text {curr }}+a_{3}+a_{4} / \ln \left(L_{m e m}^{\text {curr }}\right)\right]}{\left[a_{0}+a_{1} \cdot T^{r e f}+a_{2} \cdot R H^{r e f}+a_{3}+a_{4} / \ln \left(L_{m e m}^{r e f}\right)\right]} \times(1.12 \cdot U-0.06)$

Based on the values of the degradation rate $r^{\text {curr }}(U)$, the membrane thickness and membrane conductivity in the degraded state are computed by Eqs. (6) and (7) correspondently:

$\mathrm{L}_{\text {mem }}^{\mathrm{t}}=\mathrm{L}_{\text {mem }}^{0} \cdot\left(1-\mathrm{t} \cdot r_{L_{\text {mem }}}^{\text {curr }}(U)\right)$

$\sigma_{\text {mem }}^{\mathrm{t}}=\sigma_{\mathrm{mem}}^{0} \cdot\left(1-\mathrm{t} \cdot r_{\sigma_{\text {mem }}}^{\mathrm{curr}}(\mathrm{U})\right)$

\section{Acid group concentration}

The calculation of the acid group concentration in the membrane is followed from the percolation theory approach adopted for the ion-exchange materials in Ref. [47]. In accordance to the equation of the percolation theory, the membrane conductivity is a function of volume fraction of the conducting phase:

$\sigma_{\text {mem }}=\sigma \cdot\left(f-f_{c r}\right)^{\tau}$

where $\sigma$-pre-factor of percolation equation, $\tau$ - percolation exponent, $f$ - volume fraction of the conducting phase; $f_{c r}$ critical volume fraction of the conducting phase. The quantities $\sigma, f_{c r}$ and $\tau$ are the parameters of the percolation equation. Calculations based on the theory of probability as well as experimental investigations have shown that the percolation
In order to justify the relation (11), we analysed the experimental data published by Collette et al. [55,56]. The authors studied the time changes of membrane conductivity and ion-exchange capacity (acid group concentration) of the perfluorinated membranes Nafion 212 and Nafion 112 degraded in a climatic chamber. Fig. 4 presents the relative changes in the specific conductivity and ion-exchange capacity, measured at $\mathrm{RH}=80 \%$ and $\mathrm{T}=80^{\circ} \mathrm{C}$. In the figure, the dashed line is exponential function fitting the experimental data on the relative changes in the membrane conductivity as a function of the time. The continuous line is calculated from the fit line using Eq (11) and shows the relative changes in the acid group concentration vs time.

\section{Diffusion coefficients of the gases in the membrane}

As described above, we assume that pinholes occur at some critical membrane thickness, $L_{m e m}^{c r}$. In the present work, the model value of $L_{m e m}^{c r}$ is equal to $10 \%$ of the initial membrane thickness, $L_{\text {mem }}^{0}$ (the thickness at BoL):

$L_{\text {mem }}^{c r}=0.1 \cdot L_{m e m}^{0}$

The alteration in the gas $\left(\mathrm{O}_{2}, \mathrm{~N}_{2}, \mathrm{H}_{2}\right)$ diffusion coefficients in the membrane during the degradation is modelled as a 
function of the membrane thickness using following empirical equations:

at $\mathrm{L}_{\text {mem }}(\mathrm{t}) \geq \mathrm{L}_{\mathrm{mem}}^{\mathrm{cr}}$

$D_{g}(t)=D_{g}^{0}+9.1378 \cdot 10^{-14} \cdot\left(L_{\text {mem }}^{0}-L_{\text {mem }}(t)\right)$

at $L_{\text {mem }}(t)<L_{\text {mem }}^{c r}$

$D_{g}(t)=101 \cdot D_{g}^{0}-\left[\frac{100 \cdot D_{g}^{0}-9.1378 \cdot 10^{-14} \cdot\left(L_{\text {mem }}^{0}-L_{m e m}(t)\right)}{L_{m e m}^{c r}}\right] \cdot L_{m e m}(t)$

\section{Simulation setup}

The semi-empirical model of the membrane degradation is coupled with the basic PEMFC model of the CFD code AVL FIRE.

The stationary PEMFC performance is calculated for a fixed cell voltage and a fixed operating time. An operating time of zero corresponds to the Begin of Life (BoL). For an operating time larger than zero, the semi-empirical degradation model modifies the membrane properties locally in the membrane according to local operating parameters (such as temperature, relative humidity and voltage). The membrane thickness is modified globally. This constraint is necessary due to the occurrence of numerical difficulties in the implementation of local membrane thickness changes in the CFD code. Strongly distorted computational cells arising during the simulation runtime lead to a poor convergence behaviour of the transport equations. However, the influence of local membrane thickness changes are not expected to be all too significant, since, usually, the dependency of operating parameters on the operating time is stronger than local gradients. In a currently ongoing research project, the issue of local membrane thickness changes is revisited and efforts are made to improve the numerics of the CFD code.

(a)

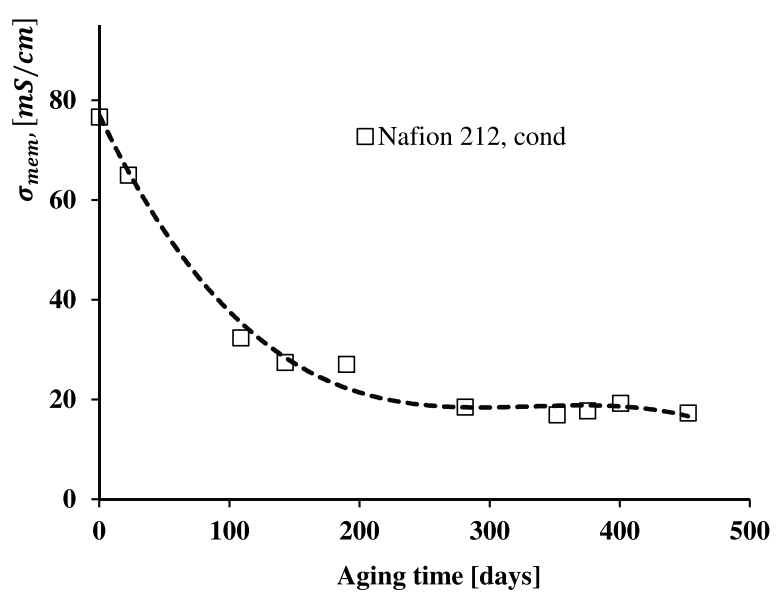

(b)

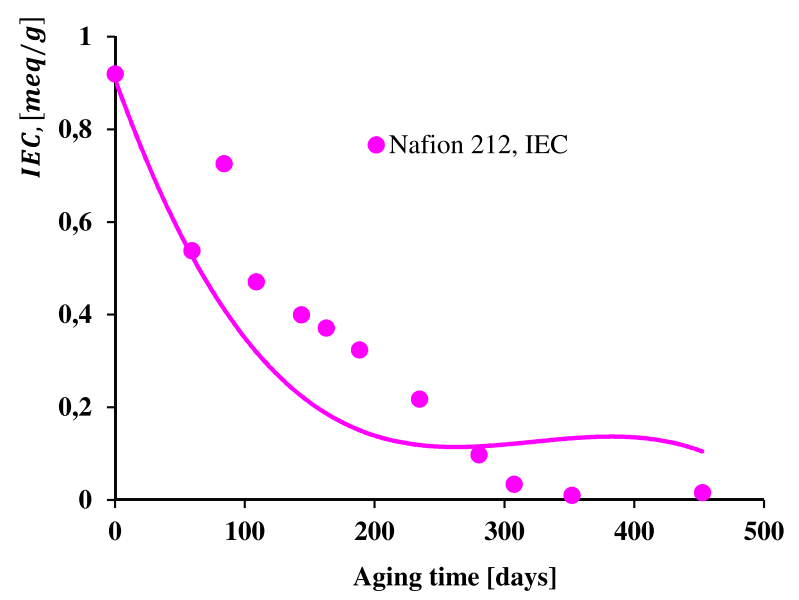

Fig. 4 - Dependencies of the conductivity (a) and ion-exchange capacity (b) of Nafion 212 vs ageing time. The symbols are experimental data from Refs. [55,56]. The membrane ageing was performed in a climatic chamber at $\mathbf{R H}=\mathbf{8 0} \%$ and $\mathrm{T}=80^{\circ} \mathrm{C}$. In Fig (a): the polynomial trend line (dashed) fits the experiment points of the membrane conductivity, (b): the continuous line is calculated from the trend line (a) using Eq. (11) with $\tau=\mathbf{1 , 4}$. 
Table 4 - Cell dimensions utilized and nominal boundary conditions applied in the simulation.

\begin{tabular}{ll} 
Description & \multicolumn{1}{c}{ Value } \\
\hline $\begin{array}{l}\text { Number of the mess cells } \\
\text { Anode/cathode channel depth, } \mathrm{m}\end{array}$ & 26,232 \\
Channel width, $\mathrm{m}$ & $2.48 \times 10^{-4}$ \\
$\quad$ Anode & $2.50 \times 10^{-4}$ \\
$\quad$ Cathode & $5.00 \times 10^{-4}$ \\
Cell length, $\mathrm{m}$ & $1.20 \times 10^{-1}$ \\
Active area, $\mathrm{m}$ & $1.20 \cdot 10^{-1} \times 7.5 \cdot 10^{-4}$ \\
Inlets & \\
Mass flow via stoichiometry $\lambda$ & \\
$\quad$ Anode & 1.5 \\
$\quad$ Cathode & 2.2 \\
$\quad \begin{array}{l}\text { Temperature, }{ }^{\circ} \mathrm{C} \\
\text { Relative humidity }\end{array}$ & 70 \\
$\quad \begin{array}{l}\text { Anode } \\
\quad \text { Cathode }\end{array}$ & 1.00 \\
Outlets & 1.00 \\
Pressure p/Pa & \\
Channel wall & 101.325 \\
Temperature, ${ }^{\circ} \mathrm{C}$ & \\
\hline
\end{tabular}

The basic PEMFC model of the CFD code AVL FIRE was developed in 2009 [59], and it includes a comprehensive 3D modelling approach that coupled thermal, electric, fluidic, and electrochemical phenomena [60,61]. In 2012, a newly developed membrane transport model was implemented in the module, which takes into account the dependencies of the water sorption isotherm and electro-osmotic coefficient of the polymer electrolyte membrane on the temperature [61]. The basic PEMFC model, applied in the work, and its experimental validation have been described in detail, in Refs. [45,61].

In the present work, the new developed degradation model is validated on a single channel fuel cell displayed in Fig. 5. The computational mesh consists of cathode, anode channels, gas diffusion layers and membrane. The location of the channel in- and outlets indicated a counter-flow configuration. At the surface on the left-hand side of the channels and

\section{Table 5 - Values of the CL and GDL properties and}

\section{constants applied in the study.}

\begin{tabular}{lll} 
Parameter & Unit & Value \\
\hline Catalyst layer & & \\
Exchange current density at cathode & $\mathrm{A} / \mathrm{m}^{3}$ & $3.2 \times 10^{5}$ \\
Exchange current density at anode & $\mathrm{A} / \mathrm{m}^{3}$ & $1.0 \times 10^{11}$ \\
Transfer coefficient at cathode & - & 0.10 \\
Transfer coefficient at anode & - & 0.50 \\
Thickness of cathode & $\mathrm{m}$ & $1.13 \times 10^{-5}$ \\
Thickness of anode & $\mathrm{m}$ & $1.13 \times 10^{-5}$ \\
Gas diffusion layer & & \\
Thickness & $\mathrm{m}$ & $3.00 \times 10^{-5}$ \\
Inplane permeability & $\mathrm{m}{ }^{2}$ & $2.33 \times 10^{-12}$ \\
Throughplane permeability & $\mathrm{m}{ }^{2}$ & $1.07 \times 10^{-14}$ \\
Porosity & - & 0.78 \\
Tortuosity & - & 1.50 \\
Contact angle & $\mathrm{deg}$ & 122 \\
Throughplane thermal conductivity & $\mathrm{W} / \mathrm{mK}$ & 4.55 \\
Throughplane electrical conductivity & $\mathrm{A} / \mathrm{mV}$ & $8.49 \times 10^{2}$ \\
Constants & & \\
Faraday constant & $\mathrm{C} / \mathrm{mol}$ & 96485.309 \\
Universal Gas Constant & $\mathrm{J} /(\mathrm{K} \mathrm{mol})$ & 8.31451 \\
\hline
\end{tabular}

Table 6 - The characteristic values of Nafion 115 membrane in initial state (before degradation) used in the simulation.

\begin{tabular}{|c|c|c|}
\hline Parameter & Unit & Value \\
\hline Thickness & $\mu \mathrm{m}$ & 124 \\
\hline Ionic conductivity & $\mathrm{A} / \mathrm{mV}$ & 5.37 \\
\hline Acid group concentration & $\mathrm{mol} / \mathrm{m}^{3}$ & 1.90 \\
\hline Water diffusion coefficient, $d_{w}^{298}$ & $\mathrm{~m}^{2} / \mathrm{s}$ & $2.68 \times 10^{-11}$ \\
\hline Electro-osmotic coefficient, $c_{\text {draa }}^{298}$ & - & $1.08 \times 10^{-1}$ \\
\hline Diffusion coefficient of $\mathrm{H}_{2}$ & $\mathrm{~m}^{2} / \mathrm{s}$ & $2.09 \times 10^{-10}$ \\
\hline Diffusion coefficient of $\mathrm{O}_{2}$ & $\mathrm{~m}^{2} / \mathrm{s}$ & $9.73 \times 10^{-11}$ \\
\hline Diffusion coefficient of $\mathrm{N}_{2}$ & $\mathrm{~m}^{2} / \mathrm{s}$ & $9.73 \times 10^{-11}$ \\
\hline Henry coefficient $\mathrm{H}_{2}$ & $\mathrm{~Pa}$ & $1.21 \times 10^{8}$ \\
\hline Henry coefficient $\mathrm{O}_{2}$ & $\mathrm{~Pa}$ & $5.14 \times 10^{8}$ \\
\hline Henry coefficient $\mathrm{N}_{2}$ & $\mathrm{~Pa}$ & $5.14 \times 10^{8}$ \\
\hline $\begin{array}{l}\text { Hydraulic permeability } \\
\text { of membrane }\end{array}$ & $\mathrm{mol} /(\mathrm{m} \cdot \mathrm{Pa} \cdot \mathrm{s})$ & $1 \times 10^{-11}$ \\
\hline $\begin{array}{l}\text { Activation energy } \\
\text { of water diffusion }\end{array}$ & $\mathrm{J} / \mathrm{mol}$ & $19.809 \times 10^{3}$ \\
\hline $\begin{array}{l}\text { Activation energy } \\
\text { of electro-osmosis }\end{array}$ & $\mathrm{J} / \mathrm{mol}$ & $7.418 \times 10^{3}$ \\
\hline $\begin{array}{l}\text { Activation energy } \\
\text { of membrane conductivity }\end{array}$ & $\mathrm{J} / \mathrm{mol}$ & $9.713 \times 10^{3}$ \\
\hline
\end{tabular}

on the right-hand side of the GDLs, symmetry boundary conditions were applied, i.e., only half of the single channel fuel cell was considered. The mesh contains 26,232 hexahedral computational cells. The catalyst layers are not the part of the mesh. They are considered as interfaces between the membrane and GDLs. Due to the fact that transport effects in the membrane are the main focus of this work and due to the strongly non-linear shape of the membrane water concentration and its large gradients a high grid resolution in the membrane has been chosen. The authors are aware of the fact that in order to resolve boundary layers or, e.g., liquid water wall films in the channels, a higher resolution of the channel

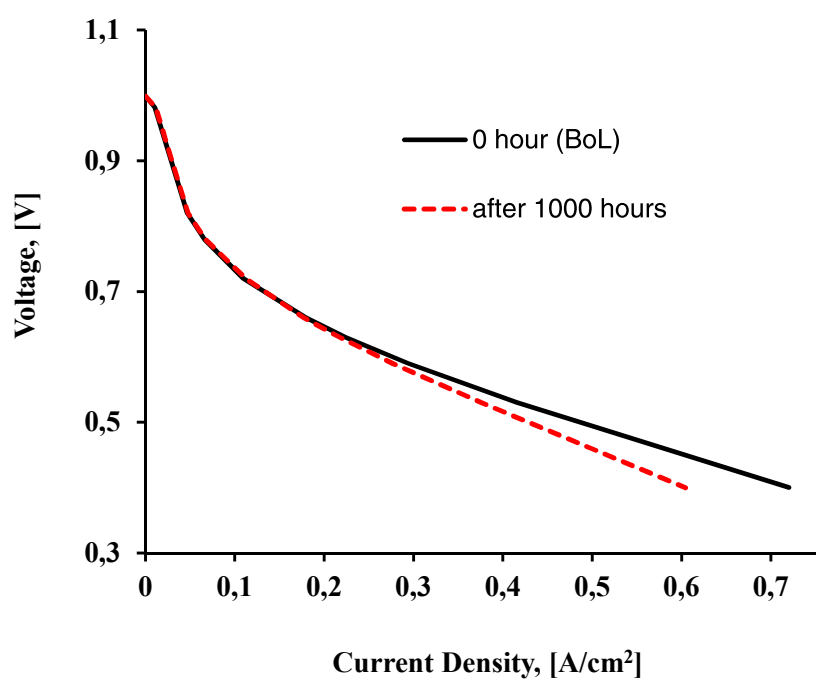

Fig. 6 - The simulation results of the polarization curves of the single channel fuel cell with Nafion115 $\left(L_{m e m}=124 \mu \mathrm{m}\right)$, at $\mathrm{p}=1.01$ bar; $\mathrm{T}=70^{\circ} \mathrm{C} ; \mathrm{RH}=100$. Solid line is the FC performance at BoL, dashed line is the performance after $1000 \mathrm{~h}$ of the operation. 
a)

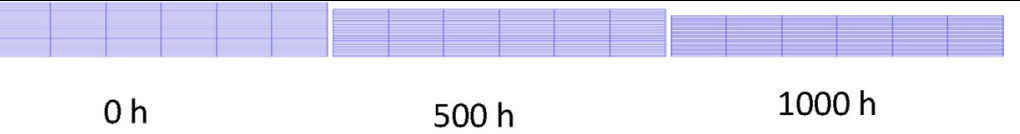

b)

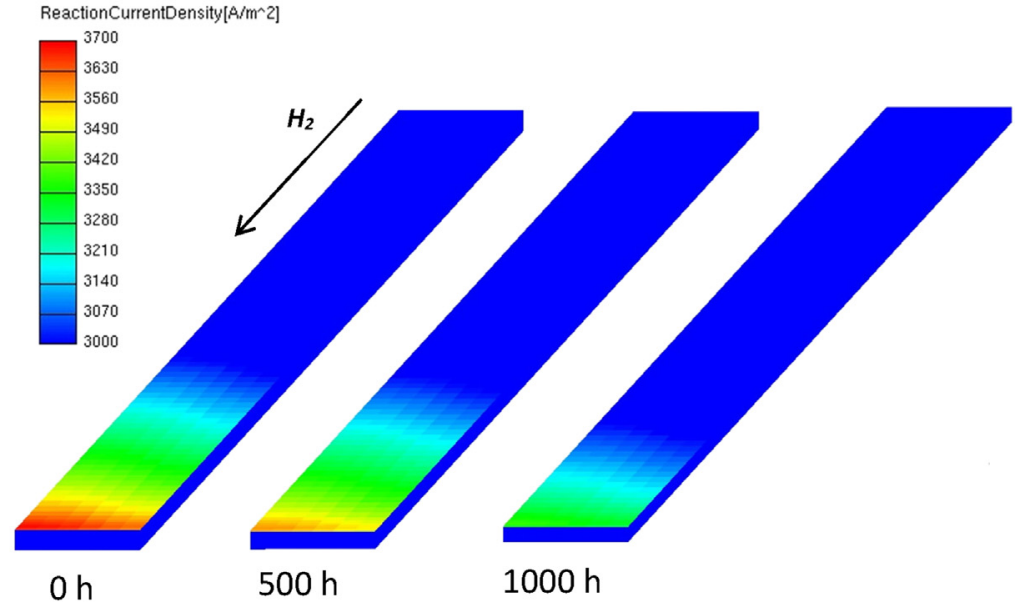

Fig. 7 - The evolution of: a) the membrane thickness and b) the current density in the membrane at the anode side. The simulation is performed on the single channel cell with Nafion $115\left(\mathrm{~L}_{\text {mem }}=124 \mu \mathrm{m}\right)$, at $\mathrm{p}=1.01 \mathrm{bar} ; \mathrm{T}=70{ }^{\circ} \mathrm{C} ; \mathrm{RH}=100 \%$.

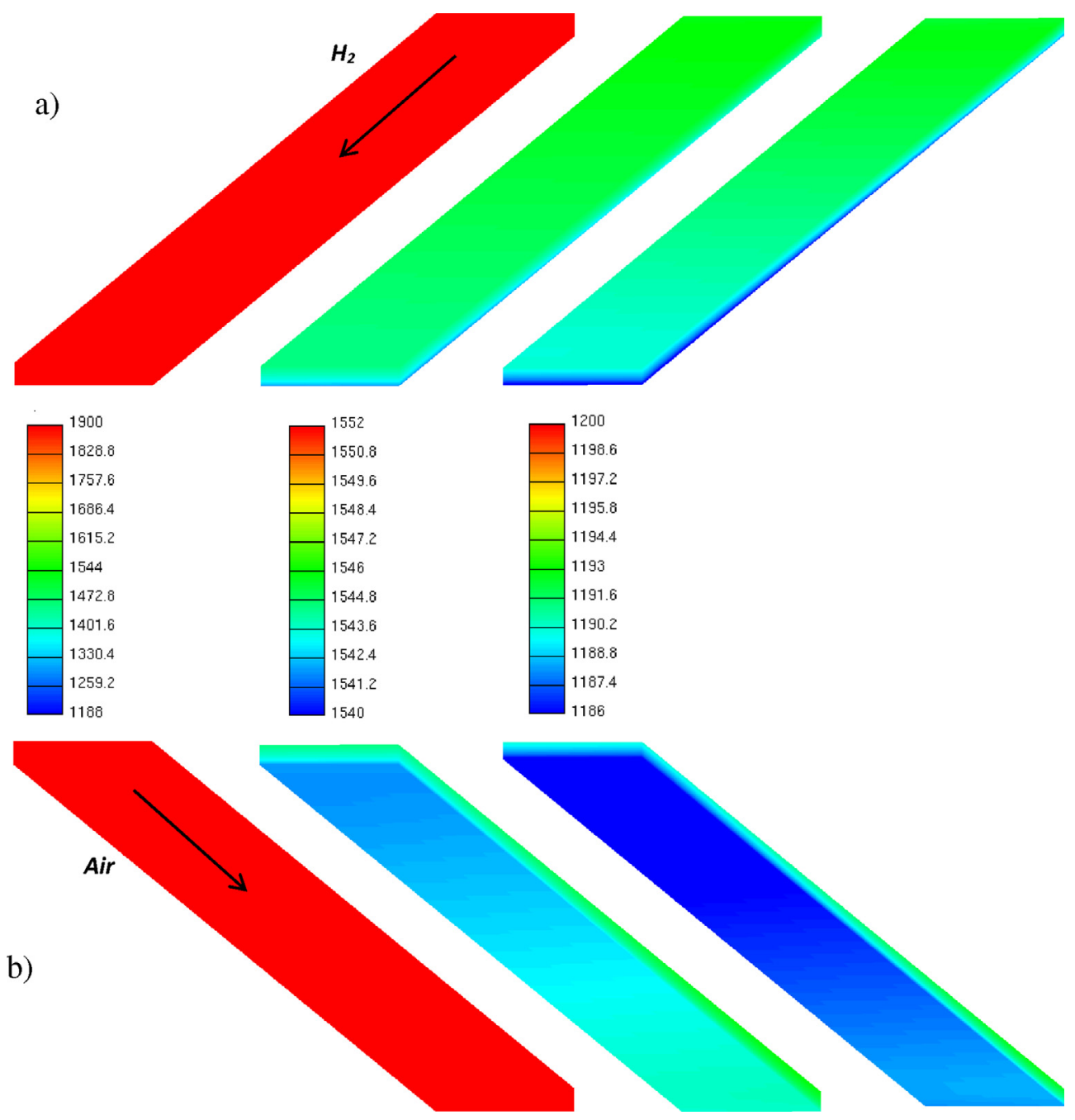

Fig. 8 - The distribution of the acid group concentration in the membrane at the anode (a) and the cathode (b) side. 
mesh would be required. However, since these effects are not focus of this work and in order to safe calculation time a rather coarse but still sufficiently accurate grid resolution has been applied here resulting in a compromise between accuracy and computational time.

Table 4 presents the boundary conditions and, Table 5 contains the values of the CL and GDL characteristics applied in the simulation. The membrane properties at BoL are listed in Table 6.

\section{Results and discussion}

The validation of the degradation model is performed on the single channel cell with membrane Nafion 115, $\mathrm{L}_{\mathrm{mem}}=124 \mu \mathrm{m}$. Fig. 6 demonstrates the calculated polarization curve of the single cell at $\mathrm{T}=70^{\circ} \mathrm{C}, \mathrm{RH}=100 \%, \mathrm{p}_{\mathrm{a}}=\mathrm{p}_{\mathrm{c}}$ 1.01 bar. The simulation indicates a decrease in the cell performance after $1000 \mathrm{~h}$ cell operation. The slope of the polarization curve slightly increases due to a raise in the membrane resistance.

Figs. 7 and 8 present 2D CFD results of the single cell performance at various operating time: 0; 500 and $1000 \mathrm{~h}$. Fig. 7a demonstrates the reduction of the membrane thickness during the degradation. Fig. $7 \mathrm{~b}$ presents the spatial distribution of the current density in the membrane at the interface to the anode. As seen from the figure, near the anode outlet/cathode inlet, the current density is higher than in other regions of the channel. In this region, the current density with the time decreases some faster than in other ones. Near the cathode inlet, the concentration of the oxygen is higher increasing the electrochemical reaction rate, raising the current density.

Unfortunately, the higher oxygen concentration accelerates the membrane chemical degradation. Fig. 8 demonstrates the alteration in the distribution of the acid group concentration. As seen, that the in-plane degradation of the membrane is non-uniform: near the cathode inlet, the acid group concentration decreases faster than in other channel regions. The locations with the larger decline of the acid group concentration correlate with the regions with increased oxygen concentration (near air inlet). The simulation results are found in agreement with the experiments reported in Refs. [62-65]. Moor et al. [62] studied a complete PEMFC stack operated in stationary mode for $12,860 \mathrm{~h}$. The in situ and ex situ analysis of the stack cells showed large differences in degradation between the cells. The cells near the air inlet showed more membrane degradation. Lin et al. [63] investigated the influence of the driving cycling on the durability of a fuel cell. The measurements of the local current distribution in a segmented showed that the current density at the exit and the inlet regions declines much faster than at the other parts. The increase of the ohmic resistance was at the cathode significantly higher than at the anode. It could be caused by a decrease in the concentration of the acid groups of the membrane, which are responsible for the proton transport.

Fig. 9 shows the time-dependent changes in the current density of the single channel cell at different relative humidity and temperature. These calculations are carried out at fixed cell voltage $\mathrm{U}=0.63 \mathrm{~V}$. The decay of the current density is accelerated at lower relative humidity (Fig. 9a) and higher temperature (Fig. 9b). These simulation results correlate to experimental observations reported in Refs. $[64,65]$. Liu et al. [64] studied an effect of relative humidity on the membrane degradation rate analysing fluoride release during stack operation. The fluoride release increased more than one order of magnitude when the $\mathrm{RH}$ was lowered from $100 \%$ to $25 \%$. Jo et al. [65] investigated an effect of operating temperature on PEMFC degradation under startup/shutdown cycling. The in-situ measurements using electrochemical impedance spectroscopy showed that the ohmic resistance increases faster at higher temperature. The higher ohmic resistance caused larger decay of the cell current. These experimental results are found in agreement with the present simulation, confirming the validity of the proposed degradation model.

In our other paper, Fink et al. [66] demonstrate the applicability of the developed degradation model to simulate the
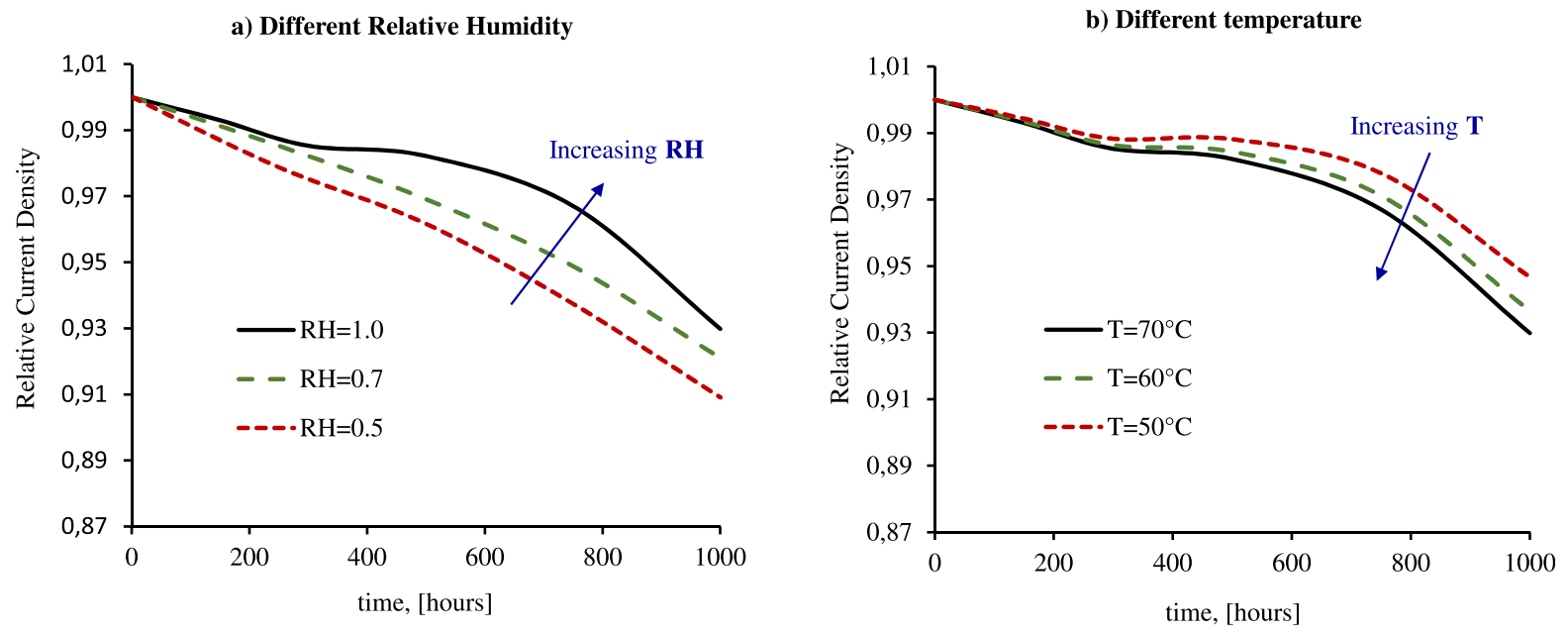

Fig. 9 - The relative changes in the fuel cell current density vs operating time at different: a) relative humidity and b) temperature. The simulation is performed on the single channel cell with Nafion $115\left(L_{m e m}=124 \mu \mathrm{m}\right)$, at $p=1.01$ bar. In figure a) $\mathrm{T}=70^{\circ} \mathrm{C}$, in figure b) $\mathrm{RH}=100 \%$. 
performance of an air-cooled PEMFC stack as a function of operating time. The simulation is applied to analyse timedependent changes in the spatial distribution of the temperature and current density. The calculated values at 2000 , 4000 and $6000 \mathrm{~h}$ are found in good agreement with measured ones.

\section{Conclusion}

The paper describes the development of a new degradation model to simulate and analyse the performance of the polymer electrolyte fuel cell as a function of time. The new model consists of two main parts: 1) a novel semiempirical degradation model, which is coupled with 2) basic PEMFC model of the CFD code AVL FIRE. The semiempirical model of the membrane degradation is based on the assumption that the degradation rates of the membrane depend on the oxygen crossover rate. The proposed degradation model enables to consider the influence of the local operating conditions such as temperature, relative humidity and voltage on the degradation rates of the following membrane properties: ionic conductivity, acid group concentration and gas diffusion coefficients. The time-dependent changes in the membrane thickness are modelled globally.

The preliminary testing of the proposed degradation model is carried out on a single channel cell. The calculated polarization curves of the single channel cell at BoL and after $1000 \mathrm{~h}$ operation are performed using the degradation rates of the membrane thickness and membrane conductivity estimated from experimental data published by Yuan et al. [57,58]. The 3D CFD analysis of the single cell performance at different operating time shows that the decrease of the acid group concentration and membrane conductivity is non-uniform and depends on the local operating conditions.

Also, the degradation model is applied to simulate the evolution of the cell current density at fixed cell voltage $(\mathrm{U}=0.63 \mathrm{~V})$ at different temperature and relative humidity. The current density decay is accelerated by increasing temperature and decreasing relative humidity corresponding to experimental observations reported in scientific papers [62-66].

\section{Acknowledgement}

The work has been financially supported by the Austrian Research Promotion Agency (FFG) and company AVL List GmbH: IV2Splus Program, Project “A3 FALCON” (No. 835811) Advanced 3D Fuel Cell Analysis and Condition Diagnostics, as well as Mobilität der Zukunft Program, Project "FC-DIAMOND" (No. 850328) - PEM Fuel Cell DegradatIon Analysis and MinimizatiON MethoDology Based on Joint Experimental and Simulation Techniques.

The corresponding author especially thanks Prof. Kulikovsky A. for the consulting.

Thanks to the reviewers for the helpful suggestions directed to improving the manuscript.

\section{R E F E R E N C E S}

[1] Upreti G, Greene DL, Duleep KG, Sawhney R. Impacts of the American recovery and reinvestment act and the investment tax credit on the North American non-automotive PEM fuel cell industry. Int J Hydrogen Energy 2016;41(5):3664-75.

[2] Klebanoff LE, Breit JS, Roe GS, Damberger T, Erbel T, Wingert S, et al. Fuel cell mobile lighting: a fuel cell market transformation project. Int J Hydrogen Energy 2014;39(24):12948-72.

[3] Jia F, Guo L, Liu H. A study on current overshoot during startups and optimal start-up strategy of proton exchange membrane fuel cells. Int J Hydrogen Energy 2015;40(24):7754-61.

[4] Chatillon Y, Bonnet C, Lapicque F. Heterogeneous aging within PEMFC stacks. Fuel Cells 2014;14(4):581-9.

[5] Hashimasa Y, Numata T. Comparison of test results on load cycle durability of polymer electrolyte fuel cell cathode catalysts. Int J Hydrogen Energy 2015;40(35):11543-9.

[6] Jahnke T, Futter G, Latz A, Malkow T, Papakonstantinou G, Tsotridis G, et al. Performance and degradation of Proton Exchange Membrane Fuel Cells: state of the art in modeling from atomistic to system scale. J Power Sources 2016;304:207-33.

[7] Mayur M, Strahl S, Husar A, Bessler WG. A multi-timescale modeling methodology for PEMFC performance and durability in a virtual fuel cell car. Int J Hydrogen Energy 2015;40(46):16466-76.

[8] Saygili Y, Kincal S, Eroglu I. Development and modeling for process control purposes in PEMs. Int J Hydrogen Energy 2015;40(24):7886-94.

[9] Verma A, Pitchumani R. Influence of transient operating parameters on the mechanical behavior of fuel cells. Int $J$ Hydrogen Energy 2015;40(26):8442-53.

[10] De Bruijn FA, Dam VAT, Janssen GJM. Review: durability and degradation issues of PEM fuel cell components. Fuel Cells 2008;8:3-22.

[11] Büchi FN, Schmidt TJ, Inaba M. Polymer electrolyte fuel cell durability. Springer; 2009. p. 1-507.

[12] Mench M, Kumbur EC, Veziroglu TN. Polymer electrolyte fuel cell degradation. Amsterdam: Elsevier; 2011.

[13] Yousfi-Steiner N, Moçotéguy P, Candusso D, Hissel D. A review on polymer electrolyte membrane fuel cell catalyst degradation and starvation issues: causes, consequences and diagnostic for mitigation. J Power Sources 2009;194:130-45.

[14] Wu J, Yuan XZ, Martin JJ, Wang H, Zhang J, Shen J, et al. A review of PEM fuel cell durability: degradation mechanisms and mitigation strategies. J Power Sources 2008;184:104-19.

[15] Virkar AV, Zhou Y. Mechanism of catalyst degradation in proton exchange membrane fuel cells. J Electrochem Soc 2007;154:B540-7.

[16] Park J, Oh H, Ha T, Lee YI, Min K. A review of the gas diffusion layer in proton exchange membrane fuel cells: durability and degradation. Appl Energy 2015;155:866-80.

[17] Zhan Y, Guo Y, Zhu J, Li L. Natural degradation and stimulated recovery of a proton exchange membrane fuel cell. Int J Hydrogen Energy 2014;39:12849-58.

[18] Banan R, Zu J, Bazylak A. Humidity and temperature cycling effects on cracks and delaminations in PEMFCs. Fuel Cells 2015;15:327-36.

[19] Placca L, Kouta R. Fault tree analysis for PEM fuel cell degradation process modelling. Int J Hydrogen Energy 2011;36:12393-405.

[20] Atrazhev VV, Timokhina EN, Burlatsky SF, Sultanov VI, Madden TH, Gummalla M. Direct mechanism of OH radicals formation in PEM fuel cells. ECS Trans 2008;6:69-74. 
[21] Ishimoto T, Koyama M. A review of molecular-level mechanism of membrane degradation in the polymer electrolyte fuel cell. Membr 2012;2:395-414.

[22] Seidenberger K, Wilhelm F, Schmitt T, Lehnert W, Scholta J. Estimation of water distribution and degradation mechanisms in polymer electrolyte membrane fuel cell gas diffusion layers using a 3D Monte Carlo model. J Power Sources 2011;196:5317-24.

[23] Malek K, Franco AA. Microstructure-based modeling of aging mechanisms in catalyst layers of polymer electrolyte fuel cells. J Phys Chem B 2011;115:8088-101.

[24] Hu J, Sui PC, Kumar S, Djilali N. Modelling and simulations of carbon corrosion during operation of a Polymer Electrolyte Membrane fuel cell. Electrochim Acta 2009;54:5583-92.

[25] Shah AA, Ralph TR, Walsh FC. Modeling and simulation of the degradation of perfluorinated ion-exchange membranes in PEM fuel cells. J Electrochem Soc 2009;156:B465-84.

[26] Kulikovsky AA. The regimes of catalyst layer operation in a fuel cell. Electrochim Acta 2010;55:6391-401.

[27] Gummalla M, Atrazhev VV, Condit D, Cipollini N, Madden T, Kuzminyh NY, et al. Degradation of polymer-electrolyte membranes in fuel cells: II. Theoretical model. J Electrochem Soc 2010;157:B1542-8.

[28] Gubler L, Dockheer SM, Koppenol WH. Radical (HO, H and HOO) formation and ionomer degradation in polymer electrolyte fuel cells. J Electrochem Soc 2011;158:B755-69.

[29] Wong KH, Kjeang E. Macroscopic in-situ modeling of chemical membrane degradation in polymer electrolyte fuel cells. J Electrochem Soc 2014;161:F823-32.

[30] Li Y, Moriyama K, Gu W, Arisetty S, Wang CY. A onedimensional Pt degradation model for polymer electrolyte fuel cells. J Electrochem Soc 2015;162:F834-42.

[31] Xie T, Hayden CA. A kinetic model for the chemical degradation of perfluorinated sulfonic acid ionomers: weak end groups versus side chain cleavage. Polymer 2007:48:5497-506.

[32] Kundu S, Fowler MW, Simon LC, Abouatallah R, Beydokhti N. Open circuit voltage durability study and model of catalyst coated membranes at different humidification levels. J Power Sources 2010;195:7323-31.

[33] Kim J, Lee J, Cho BH. Equivalent circuit modeling of PEM fuel cell degradation combined with a LFRC. IEEE Trans Ind Electron 2013;60:5086-94.

[34] Brik K, Ammar FB, Djerdir A, Miraoui A. Causal and fault trees analysis of proton exchange membrane fuel cell degradation. J Fuel Cell Sci Technol 2015;12:2443022.

[35] Yousfi Steiner N, Hissel D, Moçtéguy P, Candusso D. Diagnosis of polymer electrolyte fuel cells failure modes (flooding \& drying out) by neural networks modeling. Int $J$ Hydrogen Energy 2011;36:3067-75.

[36] Franco AA, Tembely M. Transient multiscale modeling of aging mechanisms in a PEFC cathode. J Electrochem Soc 2007;154:B712-23.

[37] Franco AA, Gerard M. Multiscale model of carbon corrosion in a PEFC: coupling with electrocatalysis and impact on performance degradation. J Electrochem Soc 2008;155:B367-84.

[38] Franco AA. Modelling and analysis of degradation phenomena in polymer electrolyte membrane fuel cells, Ch.11. In: Polymer electrolyte membrane and direct methanol fuel cell technology: fundamentals and performance of low temperature fuel cells. Woodhead Publishing Limited; 2012. p. 291-367.

[39] Robin C, Gerard M, Franco AA, Schott P. Multi-scale coupling between two dynamical models for PEMFC aging prediction. Int J Hydrogen Energy 2013;38:4675-88.

[40] Lu L, Ouyang M, Huang H, Pei P, Yang F. A semi-empirical voltage degradation model for a low-pressure proton exchange membrane fuel cell stack under bus city driving cycles. J Power Sources 2007;164:306-14.

[41] Aström K, Fontell E, Virtanen S. Reliability analysis and initial requirements for FC systems and stacks. J Power Sources 2007;171:46-54.

[42] Wieland C, Schmid O, Meiler M, Wachtel A, Linsler D. Reliability computing of polymer-electrolyte-membrane fuel cell stacks through Petri nets. J Power Sources 2009;190:34-9.

[43] Zhang X, Pisu P. Prognostic-oriented fuel cell catalyst aging modeling and its application to health-monitoring and prognostics of a PEM fuel cell. Int J Progn Health Manage 2014;5(1).

[44] Jouin M, Gouriveau R, Hissel D, Péra M, Zerhouni N. Prognostics of PEM fuel cell in a particle filtering framework. Int J Hydrogen Energy 2014;39:481-94.

[45] Karpenko-Jereb L, Sternig C, Fink C, Hacker V, Theiler A, Tatschl R. Theoretical study of the influence of material parameters on the performance of a polymer electrolyte fuel cell. J Power Sources 2015;297:329-43.

[46] Manual AVL. FIRE version 2010. Edition 11/2010. AVL List GmbH. 2010. p. 91.

[47] Berezina NP, Karpenko LV. Percolation effects in ionexchange materials. Colloid J 2000;62:676-84.

[48] Ghassemzadeh L, Holdcroft S. Quantifying the structural changes of perfluorosulfonated acid ionomer upon reaction with hydroxyl radicals. J Am Chem Soc 2013;135:8181-4.

[49] Lim C, Ghassemzadeh L, Van Hove F, Lauritzen M, Kolodziej J, Wang GG, et al. Membrane degradation during combined chemical and mechanical accelerated stress testing of polymer electrolyte fuel cells. J Power Sources 2014;257:102-10.

[50] Inaba M, Kinumoto T, Kiriake M, Umebayashi R, Tasaka A, Ogumi Z. Gas crossover and membrane degradation in polymer electrolyte fuel cells. Electrochim Acta 2006;51:5746-53.

[51] Baik KD, Hong BK, Kim MS. Effects of operating parameters on hydrogen crossover rate through Nafion ${ }^{\circledR}$ membranes in polymer electrolyte membrane fuel cells. Renew Energy 2013;57:234-9.

[52] Schalenbach M, Hoefner T, Paciok P, Carmo M, Lueke W, Stolten D. Gas permeation through Nafion. Part 1 Meas J Phys Chem C 2015;119:25145-55.

[53] Broka K, Ekdunge P. Oxygen and hydrogen permeation properties and water uptake of Nafion ${ }^{\circledR} 117$ membrane and recast film for PEM fuel cell. J Appl Electrochem 1997;27:117-24.

[54] Gode P, Lindbergh G, Sundholm G. In-situ measurements of gas permeability in fuel cell membranes using a cylindrical microelectrode. J Electroanal Chem 2002;518:115-22.

[55] Collette FM, Lorentz C, Gebel G, Thominette F. Hygrothermal aging of Nafion ${ }^{\circledR}$. J Membr Sci 2009;330:21-9.

[56] Collette FM, Thominette F, Mendil-Jakani H, Gebel G. Structure and transport properties of solution-cast Nafion ${ }^{\circledR}$ membranes subjected to hygrothermal aging. J Membr Sci 2013;435:242-52.

[57] Yuan X, Zhang S, Wang H, Wu J, Sun JC, Hiesgen R, et al. Degradation of a polymer exchange membrane fuel cell stack with Nafion ${ }^{\circledR}$ membranes of different thicknesses: Part I. in situ diagnosis. J Power Sources 2010;195:7594-9.

[58] Yuan X, Zhang S, Ban S, Huang C, Wang H, Singara V, et al. Degradation of a PEM fuel cell stack with Nafion $^{\circledR}$ membranes of different thicknesses. Part II: ex situ diagnosis. J Power Sources 2012;205:324-34.

[59] Fink C. Modelling and simulation of multiphase transport phenomena in porous media with application to PEM fuel cell. 2009. PhD Thesis. Graz. Austria. 
[60] Fink C, Fouquet N. Three-dimensional simulation of polymer electrolyte membrane fuel cells with experimental validation. Electrochim Acta 2011;56:10820-31.

[61] Karpenko-Jereb L, Innerwinkler P, Kelterer AM, Sternig C, Fink C, Prenninger P, et al. A novel membrane transport model for polymer electrolyte fuel cell simulations. Int $\mathrm{J}$ Hydrogen Energy 2014;39:7077-88.

[62] De Moor G, Bas C, Charvin N, Dillet J, Maranzana G, Lottin O, et al. Perfluorosulfonic acid membrane degradation in the hydrogen inlet region: a macroscopic approach. Int J Hydrogen Energy 2016;41:483-96.

[63] Lin R, Xiong F, Tang WC, Técher L, Zhang JM, Ma JX. Investigation of dynamic driving cycle effect on the degradation of proton exchange membrane fuel cell by segmented cell technology. J Power Sources 2014;260:150-8.

[64] Liu H, Zhang J, Coms FD, Gu W, Litteer B, Gasteiger HA. Impact of gas partial pressure on PEMFC chemical degradation. ECS Trans 2006;3:493-505.

[65] Jo YY, Cho E, Kim JH, Lim T, Oh I, Kim S, et al. Degradation of polymer electrolyte membrane fuel cells repetitively exposed to reverse current condition under different temperature. J Power Sources 2011;196:9906-15.

[66] Fink C, Karpenko-Jereb L, Ashton S. Advanced CFD analysis of an air-cooled PEM fuel cell stack predicting the loss of performance with time. Fuel Cells 2016. http://dx.doi.org/ 10.1002/fuce.201500163. 